\title{
THE EFFECT OF THE COAT COLOUR DILUTION GENE ON BODY SIZE IN THE MOUSE
}

\author{
L. BUTLER \\ University of Toronto
}

Received 19.iii.54

CAsTLE et al. (1936) state that mice with the dilution gene $d$ are heavier than litter mates with the intense gene. At first they, like Green (1931), assumed that the difference in weight was due to the presence of a size gene or genes on the chromosome near the locus for dilution. In later experiments which utilised the closely linked gene for short ear se, they found that the marked decrease in body size of the se segregates could not be explained by linkage of Se with size genes. They and subsequent investigators postulated that the decrease in body size in short-eared mice is a pleiotropic effect of se. As a result of this finding it was inferred without any supporting evidence that the size effects of $d$ were also pleiotropic and not the result of linkage. This untested hypothesis has been widely accepted. Castle (1940) states " The largest race of mice producible by selection should include the genetic constitution $A^{y} b b d d$, since this genetic aggregation would tend to increase body size over what it would otherwise be". MacArthur (1949) in his selection experiments found that his large race were mostly $d d b b$ while his small race selected from the same foundation stock were $D D B B$. He considered that this was consistent with expectation, so no test crosses or counter-selections were made to check the hypothesis of pleiotropic effects. Grüneberg (r952) is somewhat reluctant to accept Castle's hypothesis because alternative explanations are possible, such as, a size gene linked to $d$ could be over-compensated by the contrary effect of se. In summarising, he states, "Nonetheless, taking all the pieces of evidence together, there seems little doubt that the size effects of $b, d, s e, \ldots$. are pleiotropic effects of the genes themselves."

The evidence for the effect on body size of the dilution gene is given in all Castle's later papers, and in Gruneberg's, as the percentage increase in body size caused by the dilution mutation. It is shown that dilute males are $2 \cdot 30$ per cent. larger than intense ones, and that dilute females are 2.47 per cent. heavier than intense females. The heterozygote is said to have no effect. It is interesting to examine the basis for these often-quoted percentages and for the table given in Grüneberg on page 407. If we utilise the given probable errors of the means to get standard errors of the differences, we find that in males the dilution gene increases body size by $0.67 \pm 0.27$ grams in one cross and $0.66 \pm 0.55$ grams in the other cross; therefore the 
2.3 per cent. increase in one cross is significant while the $2 \cdot 31$ per cent. in the other is not. In the females the increases are $0.49 \pm 0.19$ and $1.49 \pm 0.50$, therefore both the $\mathrm{I} \cdot 86$ and the 6.54 per cent. are significant. However, the large variation in the magnitude of these differences renders them suspect. In the next series of crosses the differences were smaller than those given above and were nonsignificant. In Green's crosses when the triple recessives $d b a$ were compared with $D B A$, there was no significant difference in the males but there was one in the females. When the dilution mutation was considered alone there was no significant difference in weight between the two classes of segregates.

In studying the segregation of weight in crosses involving mice with large, normal, or small body size, Butler (1952), obtained some ancillary information on the effect of coat colour genes on body size. This material was not published because it seems naive to expect strong linkages between a major gene and genes for size, if these polygenes which bring about body size are as numerous as they appear. In view of the fact that the above mentioned hypothesis of the pleiotropic effects of $d$ and $b$ on body size is widely held and is in danger of being accepted at face value in modern reviews and texts, the pertinent data from these tests are given for the $d$ mutant in the accompanying table. In none of the crosses was there a significant difference in body size between black and brown segregates, or between intense and dilute segregates, in spite of the fact that the segregates in one cross ranged in size from 14 to 36 grams. The table shows that in both $\mathrm{F}_{2}$ and backcross generations the dilute segregants were smaller instead of larger than the intense ones. In the first three crosses, the $d$ gene came from the parent with large body size, which was MacArthur's large (L) strain with body size of $33^{.6}$ grams. In no case is the amount by which the mean weight of the intense segregates exceeds the mean weight of the dilute ones, statistically significant, but in all cases the difference is in the same direction and opposite to what would be expected from pleiotropy. While these results are contrary to those expected on the hypothesis that one pleiotropic effect of $d$ is to increase body size, it can be argued that the expected pleiotropic effect is so small that segregation of other size genes could obscure it. To eliminate this criticism we need to observe the size affects of $D$ and $d$ when the rest of the genotypic background is identical. A segregating inbred line is ideal for this purpose, and the lower half of the table gives data from such a line.

The $p b s$ line was set up in 1949 from selected segregates of a cross between McGill and Toronto strains. The line was established by brother $\times$ sister mating and in the first generations the only selection applied was for general vigour. After Sir R. A. Fisher had visited our laboratory and pointed out the superiority of segregating inbred lines over standard inbred ones, we decided to maintain some of our 
stocks in this form. Since the pbs line was still heterozygous for $D d$ we mated an intense brother with his dilute sisters, and vice versa in all generations after the eighth. The line is fairly vigorous although there has been some infertility and a decline in weight, from $22 \cdot \mathrm{I}$ for males and 20.3 for females, to the values given in the table. The data in the table show that in this inbred line, with its fairly uniform

TABLE

Sixty-day weights for intense and dilute mice

\begin{tabular}{|c|c|c|c|c|c|c|}
\hline \multirow{2}{*}{\multicolumn{2}{|c|}{ Cross }} & \multirow{2}{*}{ Type } & \multicolumn{2}{|c|}{ Males } & \multicolumn{2}{|c|}{ Females } \\
\hline & & & Number & Mean & Number & Mean \\
\hline \multirow{2}{*}{\multicolumn{2}{|c|}{$(\mathbf{L} \times \mathbf{N}) \mathbf{F}_{2}$}} & $\begin{array}{l}D \\
d\end{array}$ & $\begin{array}{l}88 \\
33\end{array}$ & $\begin{array}{l}28 \cdot 1 \pm 0 \cdot 3^{8} \\
27 \cdot 1 \pm 0 \cdot 4^{8}\end{array}$ & \multirow[t]{2}{*}{$\begin{array}{l}90 \\
24\end{array}$} & $\begin{array}{l}23 \cdot 8 \pm 0 \cdot 31 \\
22 \cdot 9 \pm 0 \cdot 39\end{array}$ \\
\hline & & $D-d$ & & $\mathrm{I} \cdot 0 \pm 0 \cdot 6 \mathrm{r}$ & & $0.9 \pm 0.48$ \\
\hline \multirow[t]{2}{*}{$(\mathbf{L} \times \mathbf{N})$ B.C. } & \multirow[t]{2}{*}{. } & $\begin{array}{l}D \\
d\end{array}$ & \multirow[t]{2}{*}{$\begin{array}{l}43 \\
45\end{array}$} & $\begin{array}{l}31 \cdot 6 \pm 0 \cdot 36 \\
31 \cdot 2 \pm 0 \cdot 36\end{array}$ & \multirow[t]{2}{*}{$\begin{array}{l}40 \\
35\end{array}$} & $\begin{array}{l}26 \cdot 5 \pm 0 \cdot 38 \\
25 \cdot 9 \pm 0 \cdot 39\end{array}$ \\
\hline & & $D-d$ & & $0.4 \pm 0.5^{1}$ & & $0.6 \pm 0.54$ \\
\hline \multirow{2}{*}{\multicolumn{2}{|c|}{$(\mathbf{L} \times p b s) \mathbf{F}_{\mathbf{2}}$}} & $\begin{array}{l}D \\
d\end{array}$ & $\begin{array}{r}102 \\
43\end{array}$ & $\begin{array}{l}26 \cdot 7 \pm 0 \cdot 36 \\
26 \cdot 3 \pm 0 \cdot 51\end{array}$ & \multirow[t]{2}{*}{$\begin{array}{l}82 \\
29\end{array}$} & $\begin{array}{l}23 \cdot 4 \pm 0 \cdot 52 \\
22 \cdot 4 \pm 0 \cdot 55\end{array}$ \\
\hline & & $D-d$ & & $0.4 \pm 0.63$ & & $1 \cdot 0 \pm 0 \cdot 76$ \\
\hline \multirow{2}{*}{\multicolumn{2}{|c|}{$\begin{array}{l}\text { Inbred pbs } \\
\quad \text { generations 9-1 I }\end{array}$}} & $\begin{array}{l}D \\
d\end{array}$ & $\begin{array}{l}21 \\
43\end{array}$ & $\begin{array}{l}21 \cdot 03 \pm 0 \cdot 58 \\
19 \cdot 73 \pm 0 \cdot 36\end{array}$ & \multirow[t]{2}{*}{$\begin{array}{l}39 \\
23\end{array}$} & $\begin{array}{l}18 \cdot 27 \pm 0 \cdot 68 \\
17 \cdot 76 \pm 0 \cdot 63\end{array}$ \\
\hline & & $D-d$ & & $0.30 \pm 0.68$ & & $0.5^{1} \pm 0.93$ \\
\hline \multirow{2}{*}{\multicolumn{2}{|c|}{ generations 12-14 }} & $\begin{array}{l}D \\
d\end{array}$ & $\begin{array}{l}24 \\
27\end{array}$ & $\begin{array}{l}19.05 \pm 0.70 \\
17.41 \pm 0.54\end{array}$ & \multirow[t]{2}{*}{$\begin{array}{l}38 \\
26\end{array}$} & $\begin{array}{l}16 \cdot 24 \pm 0.40 \\
15 \cdot 68 \pm 0.56\end{array}$ \\
\hline & & $D-d$ & & $\mathrm{I} \cdot 64 \pm 0.88$ & & $0.5^{6} \pm 0.68$ \\
\hline \multirow{2}{*}{\multicolumn{2}{|c|}{ generations $15^{-1} 7$}} & $\begin{array}{l}D \\
d\end{array}$ & $\begin{array}{l}26 \\
12\end{array}$ & $\begin{array}{l}18 \cdot 66 \pm 0 \cdot 42 \\
18 \cdot 01 \pm 1 \cdot 00\end{array}$ & \multirow[t]{2}{*}{$\begin{array}{l}14 \\
17\end{array}$} & $\begin{array}{l}16 \cdot 79 \pm 0 \cdot 54 \\
16 \cdot 16 \pm 0 \cdot 46\end{array}$ \\
\hline & & $D-d$ & & $0 \cdot 65 \pm \mathrm{r} \cdot 08$ & & $0.63 \pm 0.71$ \\
\hline \multirow{2}{*}{\multicolumn{2}{|c|}{ All generations }} & $\begin{array}{l}D \\
d\end{array}$ & $\begin{array}{l}71 \\
82\end{array}$ & $\begin{array}{l}19.67 \pm 0.35 \\
18.83 \pm 0.30\end{array}$ & \multirow[t]{2}{*}{$\begin{array}{l}91 \\
66\end{array}$} & $\begin{array}{l}17 \cdot 20 \pm 0 \cdot 33 \\
16 \cdot 53 \pm 0 \cdot 35\end{array}$ \\
\hline & & $D-d$ & & $0.84 \pm 0.46$ & & $0.67 \pm 0.49$ \\
\hline
\end{tabular}

genic background, there is no evidence for the suggested pleiotropic effect of $d$. In fact, while none of the differences are significant, they are all in the opposite direction to that expected. In the table, because of the small numbers involved, three generations are lumped together to give each set of data, but this lumping did not change the picture. When comparisons are made within each generation we find that of the 18 differences found, in only two cases were the 
dilute segregates heavier than the intense ones, so it appears that while the differences between the two types of segregates are not significant in any single case, the very homogeneity of these differences points to the fact that the differences are real ones rather than chance ones. The segregation ratios for $D d$ are quite good in the case of the $F_{2}$ 's and backcross but are not so consistent in the inbred line. It does not seem necessary at this time to justify this departure from the I : I ratio or its apparent association with sex.

The interpretation of these findings is that dilute does not have a pleiotropic effect on body size. If it did exhibit this pleiotropism it would be necessary to postulate in this case that linked with $D$ there was a gene or genes which increase body size, and that the effect of these genes overrides the pleiotropic effect of $d$. The law of parsimony causes us to abandon this explanation, especially since the pleiotropic effects of $d$ were not well substantiated in the first place. The two alternative explanations are either the weight differences between the two types of segregates are chance ones and no explanation is needed, or if we accept as a criteria of a small real difference the fact that the weight differentials are all in the same direction; then we have to postulate linkage. Such linkage must consist of size genes close enough to the $D$ locus that after 17 generations of inbreeding they are still on the tract of heterogeneous origin (Fisher, 1949). The length of this tract if of the enclosed type, would be between 4.5 and 5 centimorgans for the 16 th and 17 th generations of inbreeding. Further information on this point should accumulate in future generations of inbreeding when the decrease in the length of this tract will make body size genes, if they do occur in this region, homozygous. If the hypothesis of size genes linked to $D$ is accepted, then the earlier work of Castle fits into the same scheme, except that in his case the linkage was in the opposite phase. The percentage increase in body size of the $d$ segregates in his data is comparable with the percentage decreases in the present data.

Summing up, it seems advisable to abandon the hypothesis that the dilution gene has a pleiotropic effect on body size, and to substitute in its place the hypothesis that close to the $d$ locus there are genes which affect body size.

\section{REFERENCES}

BUtler, L. 1952. A study of size inheritance in the housemouse. Can. F. Zool., 30, 154-1 7 I.

CAStle, W. E., Gates, W. H., REed, s. C., AND LAW, L. W. 1936 . Studies of a size cross in mice II. Genetics, $21,310-323$.

CASTle, W. E. I940. Mammalian Genetics. Harvard University Press.

FISHER, R. A. 1949. The Theory of Inbreeding. Oliver and Boyd.

GREEN, c. v. I93I. Size inheritance and growth in a mouse species cross. $\mathcal{F}$. Exp. Zool., 59, 213-263.

GRUNEBerG, H. 1952. The Genetics of the Mouse. Martinus Nijhoff, The Hague.

MACARTHUR, J. W. 1949. Selection for small and large body size in the house mouse. Genetics, 34, 194-209. 